\title{
Citra Tubuh, Kecukupan Gizi, Status Gizi, dan Status Anemia pada Wanita Pranikah
}

\author{
Aanisah Ardiyanti ${ }^{1}$, Vitria Melani $^{*}{ }^{*}$ Nadiyah $^{1}$, Laras Sitoayu $^{2}$, Yulia Wahyuni ${ }^{1}$ \\ ${ }^{1}$ Program Studi Ilmu Gizi, Fakultas Ilmu-Ilmu Kesehatan, Universitas Esa Unggul \\ ${ }^{2}$ Program Studi Pendidikan Profesi Dietisien, Fakultas Ilmu-Ilmu Kesehatan, Universitas Esa \\ Unggul \\ Email*: vitria@esaunggul.ac.id
}

\begin{abstract}
Health is the one of readiness factors in marriage. Towards the wedding, usually the body image will be a concern. A diet to get the ideal body is often to found. The results showed that the percentage of anemia in WUS who were not married was greater than WUS who were already married. This study aimed to determine the relationship of body image, level of nutritional adequacy, nutritional status, and anemia status in premarital women.

An observational study with cross sectional approach. A number of 65 respondents were selected by accidental sampling. The data were obtained through interviews using questionnaire (respondent characteristics, body shape questionare-34), anthropometric measurements (weight, height, body mass index, nutritional status), and blood sampling (hemoglobin levels). The data were analyzed using Chi-Square Test.

The results showed a significant relationship between body image and anemia status $(p<0,05)$. There was no significant relationship between the level of energy sufficiency, protein, fat, iron, zinc, and vitamin $C$ with anemia status $(p>0,05)$. There was no significant relationship between nutritional status and anemia status $(p>0,05)$. The conclusion is that only body image has a significant relationship to anemia status.
\end{abstract}

Key words : anemia, body image, nutrition

Submitted : 2020-12-26 Accepted : 2021-08-30 Published : 2021-11-08

rendah (BBLR) (Negash et al., 2015).

\section{PENDAHULUAN}

Wanita usia subur (WUS) sebagai calon pengantin (Catin) harus mempersiapkan kesehatannya sebagai salah satu faktor kesiapan pernikahan, karena pada akhirnya mereka akan menjadi seorang ibu. Status gizi pada masa pranikah akan sangat berpengaruh terhadap outcome kehamilan. Ibu yang memiliki IMT rendah $\left(<18,5 \mathrm{~kg} / \mathrm{m}^{2}\right)$ berisiko melahirkan anak dengan berat badan lahir
Hasil Riskesdas 2018 menjelaskan sebesar $84,6 \%$ kejadian anemia pada ibu hamil diderita pada wanita dengan kategori usia 15-24 tahun. Artinya kejadian anemia pada wanita usia subur (15-49 tahun) masih cukup tinggi, baik dengan keadaan sebelum maupun setelah menikah. Hasil data statistik Dinas Kesehatan Kota Depok tahun 2016 menunjukkan dari 10.200 remaja putri, $36,6 \%$ diantaranya menderita anemia. Hasil penelitian lain di Depok 
menunjukkan bahwa sebesar $63,4 \%$ remaja putri masih mengalami anemia (Simanungkalit \& Simarmata, 2019).

Menjelang pernikahan perhatian terhadap citra tubuh dapat mengalami peningkatan. Beberapa wanita melakukan berbagai cara terkait kecantikan pranikah, di antaranya menurunkan berat badan, diet, dan berolahraga (Prichard I \& Tiggemann M, 2008). Citra tubuh sangat dipengaruhi oleh lingkungan (Paratmanitya et al., 2012). Rasa percaya diri ataupun rasa minder merupakan hasil dari citra tubuh (Amar et al., 2018). Wanita memang menjadikan orang lain yang memiliki tubuh ideal sebagai panutan (Jain et al., 2015).Bbiasanya mereka akan mengubah kebiasaan makan untuk mencapai keinginannya tersebut.

Maraknya persepsi citra tubuh dan perubahan perilaku makan diduga dapat memengaruhi status gizi seseorang karena berkaitan dengan tingkat kecukupan gizi. Hal ini ditunjukkan pada penelitian yang menyebutkan bahwa terdapat hubungan yang signifikan antara citra tubuh dan status gizi. Remaja putri dengan citra tubuh negatif biasanya disertai oleh status gizi yang tidak normal (Yusintha \& Adriyanto, 2018).

Selain citra tubuh dan perilaku diet, kadar hemoglobin catin wanita juga menjadi faktor yang perlu diperhatikan. Rendahnya kadar hemoglobin menjadi indikasi terjadinya Anemia Gizi Besi (AGB). Seseorang yang memiliki citra tubuh negatif lebih besar kemungkinannya terkena anemia (Aminullah, 2016). Penelitian lainnya turut menunjukkan bahwa terdapat hubungan yang signifikan antara body image dan status anemia (Badjree \& Muniroh, 2017).

Sebuah penelitian menunjukkan hasil bahwa persentase kejadian anemia pada WUS yang belum menikah lebih besar $(14,3 \%)$ dibandingkan dengan WUS yang sudah menikah (6\%). Persentase kejadian anemia juga paling tinggi dialami oleh mereka yang status gizinya rendah (IMT $<18,5 \mathrm{~kg} / \mathrm{m}^{2}$ ). Selain itu, tingkat kecukupan gizi juga berhubungan dengan kejadian anemia. Hasil penelitian menunjukkan kejadian anemia terjadi pada mereka yang defisit konsumsi zat gizi (Sudikno \& Sandjaja, 2016).

Tujuan penelitian ini adalah untuk mengetahui hubungan citra tubuh, tingkat kecukupan gizi, status gizi, dan status anemia pada wanita pranikah di KUA Kecamatan Bojongsari Kota Depok. Keterbaruan dalam penelitian ini adalah belum pernah ada yang melakukan penelitian pada calon pengantin, khususnya di lokasi KUA yang bersangkutan menggunakan variabel terpilih.

\section{METODE PENELITIAN}


Jenis penelitian ini adalah obervasional deskriptif dengan pendekatan cross sectional. Pengambilan data penelitian dilakukan pada Desember 2019 hingga Januari 2020. Populasi dalam penelitian ini adalah seluruh WUS yang terdaftar di KUA Kecamatan Bojongsari Kota Depok. Pengambilan sampel menggunakan metode accidental sampling dan didapatkan sampel sebanyak 65 orang. Kriteria inklusi dalam penelitian ini yaitu wanita yang akan melakukan pernikahan pertama kali, berumur 20-35 tahun, dan bersedia mengikuti penelitian. Sedangkan kriteria eksklusinya yaitu subjek yang sedang menjalani diet karena penyakit tertentu dan menolak/tidak bersedia melanjutkan penelitian.

Data citra tubuh diperoleh menggunakan body shape questionnaire (BSQ-34) yang berisi 34 pertanyaan. Kecukupan gizi diperoleh melalui wawancara food recall 2x24 jam yang dilakukan saat hari biasa (weekday) dan hari libur (weekend). Status gizi diperoleh dengan perhitungan indeks massa tubuh (IMT). Status anemia diperoleh dengan pengambilan sampel darah menggunakan alat pengukur $\mathrm{Hb}$ digital yang dilakukan oleh tenaga kesehatan terlatih (bidan).

Analisis univariat dilakukan untuk melihat sebaran frekuensi responden di setiap variabel (umur, pendidikan, pekerjaan, pendapatan, status anemis, citra tubuh, dan status gizi). Analisis bivariat menggunakan uji Chi-Square. Hal ini dikarenakan, peneliti ingin melihat hubungan antara variabel independen dan variabel dependen, serta gambaran distribusi frekuensi berdasarkan kedua variabel tersebut.

Setelah dilakukan cleaning data, dari 65 data responden yang terkumpul, hanya 63 data yang digunakan dalam analisis karena adanya data menyimpang dan dianggap mengganggu.

Penelitian ini telah lolos kaji etik oleh Tim Komisi Etik Penelitian Universitas Esa Unggul dengan nomor: 0513-19.475/DPKE/KEP/FINAL-

EA/UEU/XI/2019.

\section{HASIL DAN PEMBAHASAN}

\section{Karakteristik Responden}

Pada penelitian ini, terdapat 63 data responden yang dianalisis. Distribusi frekuensi karakteristik responden dapat dilihat pada tabel 1 . 
Tabel 1. Karakteristik Responden

\begin{tabular}{|c|c|c|}
\hline Karakteristik & $\mathbf{n}$ & $\%$ \\
\hline \multicolumn{3}{|l|}{ Umur } \\
\hline Remaja Akhir & 45 & 71,4 \\
\hline Dewasa Awal & 18 & 28,6 \\
\hline \multicolumn{3}{|l|}{ Pendidikan } \\
\hline SMP & 6 & 9,5 \\
\hline SMA & 26 & 41,3 \\
\hline Perguruan Tinggi & 31 & 49,2 \\
\hline \multicolumn{3}{|l|}{ Pekerjaan } \\
\hline Pedagang/wiraswasta & 3 & 4,8 \\
\hline Pegawai Swasta & 39 & 61,9 \\
\hline Tidak Bekerja & 10 & 15,9 \\
\hline Lainnya & 11 & 17,4 \\
\hline \multicolumn{3}{|l|}{ Pendapatan } \\
\hline <UMK Depok & 30 & 47,6 \\
\hline$\geq$ UMK Depok & & 52,4 \\
\hline \multicolumn{3}{|l|}{ Status Anemia } \\
\hline Anemia & & 66,7 \\
\hline Tidak Anemia & 42 & 33,3 \\
\hline \multicolumn{3}{|l|}{ Citra Tubuh } \\
\hline Negatif & & 11,1 \\
\hline Positif & 7 & 88,9 \\
\hline \multicolumn{3}{|l|}{ Status Gizi } \\
\hline Kurang/kurus & & 4,8 \\
\hline Normal & 3 & 66,7 \\
\hline \multirow{2}{*}{ Lebih } & 42 & 28,5 \\
\hline & 28 & \\
\hline Jumlah & 63 & 100,0 \\
\hline
\end{tabular}

Berdasarkan Tabel 1 mayoritas responden berada pada kelompok umur remaja akhir (17-25 tahun) yaitu sebesar $71,4 \%$. Sebanyak 49,2\% responden dengan latar belakang pendidikan perguruan tinggi. Kebanyakan dari responden bekerja sebagai pegawai swasta (61,9\%). Sebanyak 52,4\% responden memiliki pendapatan perbulan $\geq$ UMK Depok (Rp3.872.551,72). Sebanyak $66,7 \%$ responden mengalami anemia. Citra tubuh responden cenderung positif $(88,9 \%)$. Sementara itu, status gizi responden mayoritas normal $(66,7 \%)$.

Pengklasifikasian umur mengacu pada ketentuan WHO 2009. Karakteristik remaja akhir ditandai dengan adanya kestabilan kondisi fisik dan psikis, kematangan dalam berpikir dan emosional, serta mampu menentukan perhatian terhadap masalah seksual (Putro, 2017). BKKBN menyebutkan umur ideal menikah untuk perempuan adalah 20-25 tahun.

Kebanyakan responden masih memikirkan bahwa pendidikan harus diutamakan sebelum menikah. Sebuah penelitian menyebutkan bahwa perempuan dengan tingkat pendidikan yang tinggi menikah dalam usia yang tepat (tidak menikah dini) (Syafangah, 2017). Pekerjaan dan pendapatan responden menandakan bahwa mereka sudah cukup matang dalam persiapan rumah tangga jangka panjang. Sesuai dengan penelitian yang menyebutkan bahwa kestabilan ekonomi menjadi salah satu faktor penting untuk kelangsungan fisik dan mental anggota keluarga nantinya (Sari et al., 2016). Penelitian lainnya juga menyebutkan bahwa salah satu tanda yang menjadi faktor kesiapan menikah adalah masalah finansial (Rahmah, 2018). 


\section{Hubungan Citra Tubuh dan Status}

Anemia

\section{Tabel 2. Hubungan Citra Tubuh dan Status Anemia}

Responden yang mengalami anemia proporsinya lebih banyak memiliki citra tubuh positif. Citra tubuh positif yang dimaksud adalah responden yang memiliki persepsi mengenai bentuk tubuh yang benar dan memiliki bentuk penghargaan yang baik terhadap tubuhnya sendiri. Nilai $p(\mathrm{p}<0,05)$ pada tabel 2 menunjukkan bahwa terdapat hubungan yang signifikan antara citra tubuh dan anemia. Nilai statistik dibaca menggunakan fisher's exact karena terdapat sel dengan nilai frekuensi harapan kurang dari 5.

Fenomena ini memiliki hubungan yang signifikan karena adanya perubahan perilaku yang sangat drastis, yaitu melakukan pembatasan asupan menjelang pernikahan untuk mendapatkan kepuasan pada penampilan mereka. Sejalan dengan sebuah penelitian yang menyebutkan bahwa sebagian besar wanita dengan citra tubuh positif mengalami anemia. Hal ini disebabkan pada mayoritas responden yang memiliki citra tubuh positif, mereka benarbenar berusaha menjaga segala asupan makan yang masuk bahkan cenderung membatasi dengan tujuan mempertahankan bentuk/ukuran tubuh hingga menjelang hari pernikahan. Secara tidak sadar beberapa makanan yang dijaga tersebut, kurang diperhatikan dari segi kualitas zat gizi yang dikonsumsi. Mereka hanya fokus pada zat gizi makro. Sehingga dalam pemenuhan zat gizi mikro kurang

\begin{tabular}{|c|c|c|c|c|c|c|c|}
\hline \multirow{3}{*}{$\begin{array}{c}\text { Citra } \\
\text { Tubuh }\end{array}$} & \multicolumn{3}{|c|}{ Status Anemia } & \multicolumn{3}{|c|}{ Total } & \multirow[t]{3}{*}{$p$} \\
\hline & \multicolumn{2}{|c|}{ Anemia } & \multirow{2}{*}{$\begin{array}{c}\text { Tidak } \\
\text { Anemi } \\
\mathbf{a}\end{array}$} & \multirow[b]{2}{*}{$\%$} & \multirow[b]{2}{*}{$\mathbf{n}$} & \multirow[b]{2}{*}{$\%$} & \\
\hline & $\mathbf{n}$ & $\%$ & & & & & \\
\hline Negatif & 1 & 1,6 & 6 & 9,5 & 7 & 11,1 & \multirow{2}{*}{0,004} \\
\hline Positif & 41 & 65,1 & 15 & 23,8 & 56 & 88,9 & \\
\hline Total & 42 & 66,7 & 21 & $\mathbf{3 3 , 3}$ & 63 & 100,0 & \\
\hline
\end{tabular}

tercukupi. Akibatnya terjadi

ketidakseimbangan dalam darah dan menyebabkan anemia (Fatimah et al., 2016).

Penelitian ini berbanding terbalik dengan teori yang menyatakan bahwa anemia biasanya terjadi pada wanita yang memiliki citra tubuh negatif karena mereka cenderung ingin memperbaiki keadaan tubuhnya yang dianggap tidak sesuai. Akibatnya mereka akan mengalami gangguan makan (Li et al., 2012). Dua dari sepuluh wanita dengan risiko gangguan makan terbukti mengalami anemia (Syah \& Asna, 2018).

Perbedaan yang terjadi antara penelitian ini dengan teori yang ada kemungkinan dapat terjadi karena adanya distorsi citra tubuh. Menurut Families Empowered and Supporting Treatment of Eating Disorder (FEAST), 
distorsi citra tubuh merupakan ketidaksesuaian antara ukuran tubuh dengan persepsi mengenai ukuran tubuh itu sendiri. Seseorang dengan distorsi citra tubuh berisiko lebih tinggi untuk terlibat dalam perilaku makan yang menyimpang (Sulistyan et al., 2016).

Penelitian ini tidak melakukan observasi secara rinci terkait gangguan makan. Citra tubuh sangat bersifat subjektif sesuai perasaan yang sedang dialami seseorang dan itu bisa berubah-ubah. Baik citra tubuh positif maupun negatif sebenarnya memiliki risiko yang sama terkena anemia apabila terjadi distorsi citra tubuh.

\section{Hubungan Kecukupan Zat Gizi dan}

\section{Status Anemia}

Hasil uji statistik dari tingkat kecukupan zat gizi dan status anemia dapat dilihat pada tabel 3 dan 4 di bawah ini.
Tabel 3. Hubungan Kecukupan Energi, Zat Gizi Makro, dan Status Anemia

\begin{tabular}{|c|c|c|c|c|c|c|c|}
\hline \multirow{3}{*}{$\begin{array}{c}\text { Kecukupan } \\
\text { Gizi }\end{array}$} & \multicolumn{4}{|c|}{ Status Anemia } & \multirow{2}{*}{\multicolumn{2}{|c|}{ Total }} & \multirow{3}{*}{$p$} \\
\hline & \multicolumn{2}{|c|}{ Anemia } & \multicolumn{2}{|c|}{$\begin{array}{c}\text { Tidak } \\
\text { Anemia }\end{array}$} & & & \\
\hline & $\mathbf{n}$ & $\%$ & $\mathbf{n}$ & $\%$ & $\mathbf{n}$ & $\%$ & \\
\hline \multicolumn{7}{|l|}{ Energi } & \multirow{3}{*}{1,000} \\
\hline Kurang & 36 & 57,2 & 18 & 28,5 & 54 & 85,7 & \\
\hline Normal & 6 & 9,5 & 3 & 4,8 & 9 & 14,3 & \\
\hline \multicolumn{7}{|l|}{ Protein } & \multirow{3}{*}{0,271} \\
\hline Kurang & 24 & 38,1 & 15 & 23,8 & 39 & 61,9 & \\
\hline Normal & 18 & 28,6 & 6 & 9,5 & 24 & 38,1 & \\
\hline \multicolumn{7}{|l|}{ Lemak } & \multirow{3}{*}{0,108} \\
\hline Kurang & 17 & 27,0 & 13 & 20,6 & 30 & 47,6 & \\
\hline Normal & 25 & 39,7 & 8 & 12,7 & 33 & 52,4 & \\
\hline \multicolumn{7}{|l|}{ Karbohidat } & \multirow{4}{*}{1,000} \\
\hline Kurang & 40 & 63,5 & 20 & 31,7 & 60 & 95,2 & \\
\hline Normal & 2 & 3,2 & 1 & 1,6 & 3 & 4,8 & \\
\hline Total & 42 & 66,7 & 21 & 33,3 & 63 & 100,0 & \\
\hline
\end{tabular}

Tabel 4. Hubungan Kecukupan Zat

Gizi Mikro dan Status Anemia

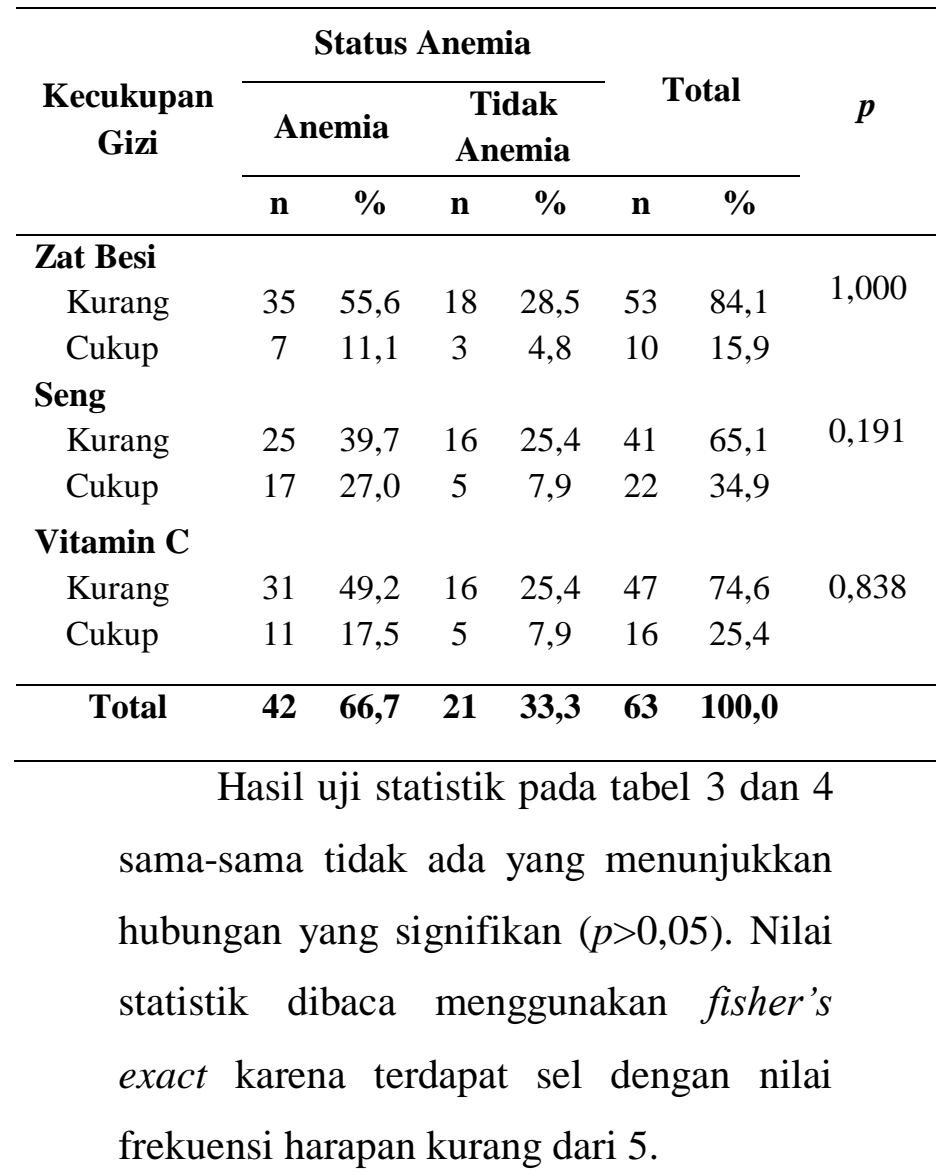


Responden yang mengalami anemia lebih banyak proporsinya pada mereka dengan tingkat kecukupan energi, protein, karbohidrat, zat besi, seng, dan vitamin $\mathrm{C}$ yang kurang $(57,2 \% ; 38,1 \% ; 63,5 \%$; $55,6 \% ; 39,7 \% ; 49,2 \%)$. Berbeda dengan lemak, responden yang mengalami anemia tingkat kecukupan asupannya normal $(39,7 \%)$.

Anemia sangat berkaitan dengan asupan makan yang kurang, terutama protein, zat besi, dan seng sebagai pembentuk hemoglobin. Terjadinya anemia tidak hanya disebabkan oleh rendahnya kuantitas asupan, namun faktor kualitas bahan makanan juga sangat memengaruhi.

Kurangnya asupan energi menyebabkan terganggunya zat gizi masuk ke dalam sel, termasuk zat besi. Protein memegang peranan penting pada pembentukan hemoglobin. Gugus sulfur yang terdapat pada protein mampu mengikat besi non-heme agar lebih mudah untuk diserap (Murray et al., 2009). Sebuah penelitian menyatakan semakin rendah asupan protein maka semakin tinggi kemungkinan terjadinya anemia (Akib \& Sumarmi, 2017).

Sintesis hemoglobin memerlukan ketersediaan zat besi dan protein yang cukup. Ketika simpanan besi tidak adekuat akan menyebabkan jumlah eritrosit protoporfirin bebas meningkat. Kemudian eritrosit mikrositik diproduksi sehingga nilai hemoglobin turun (Murray et al., 2009). Seng berperan sebagai prediktor kuat dari hemoglobin untuk biosintesis serta stimulasi eritropoesis (Houghton et $a l .$, 2016). Seng memiliki interaksi yang kuat dengan zat besi karena berperan untuk biosintesis besi heme. Vitamin C sebagai zat enhancer terhadap zat besi membantu mempercepat penyerapan besi non-heme. Vitamin $\mathrm{C}$ akan mengubah zat besi dari bentuk feri menjadi fero.

Penelitian ini sejalan dengan penelitian lain yang menyebutkan bahwa tidak terdapat hubungan yang signifikan antara kecukupan zat gizi dengan status anemia (Matayane, Bolang, \& Kawengian, 2014). Namun, hasil penelitian ini juga menunjukkan perbedaan dengan sejumlah teori yang menyatakan adanya hubungan signifikan antara kecukupan zat gizi dengan status anemia. Kecukupan zat gizi sangat dipengaruhi oleh usia, jenis kelamin, jenis aktivitas, ketersediaan pangan, kualitas zat gizi yang dikonsumsi, interaksi antar zat gizi, serta kemampuan penyerapan zat gizi di dalam usus.

Beberapa faktor yang berkaitan dengan kecukupan zat gizi tidak diteliti lebih lanjut untuk dikaitkan dengan kejadian anemia. Berdasarkan data yang diperoleh banyak responden yang kurang memfokuskan pada keseimbangan zat gizi yang dikonsumsi. Seperti halnya banyak 
responden yang mengonsumsi teh bersamaan dengan jam makan. Kandungan tanin dalam teh tanpa diimbangi asupan vitamin $\mathrm{C}$ yang cukup akan menghambat penyerapan zat besi (Muchlisa, 2013).

\section{Hubungan Status Gizi dan Status}

\section{Anemia}

Di bawah ini merupakan hasil analisis status gizi dan status anemia.

\begin{tabular}{|c|c|c|c|c|c|c|c|}
\hline \multirow{3}{*}{$\begin{array}{c}\text { Status } \\
\text { Gizi }\end{array}$} & \multicolumn{4}{|c|}{ Status Anemia } & \multirow{2}{*}{\multicolumn{2}{|c|}{ Total }} & \multirow{3}{*}{$p$} \\
\hline & \multicolumn{2}{|c|}{ Anemia } & \multicolumn{2}{|c|}{$\begin{array}{c}\text { Tidak } \\
\text { Anemia }\end{array}$} & & & \\
\hline & $\mathbf{n}$ & $\%$ & $\mathbf{n}$ & $\%$ & $\mathbf{n}$ & $\%$ & \\
\hline Kurus & 2 & 3,2 & 1 & 1,5 & 3 & 4,7 & \multirow{3}{*}{0,490} \\
\hline Normal & 30 & 47,6 & 12 & 19,1 & 42 & 66,7 & \\
\hline Lebih & 10 & 15,9 & 8 & 12,7 & 18 & 28,6 & \\
\hline Total & 42 & 66,7 & 21 & $\mathbf{3 3 , 3}$ & 63 & 100,0 & \\
\hline
\end{tabular}

Berdasarkan tabel 5 tidak terdapat hubungan signifikan antara status gizi dan status anemia $(p>0,05)$. Nilai statistik dibaca menggunakan pearson chi-square. Rata-rata responden yang memiliki citra tubuh positif terdistribusi pada status gizi yang normal. Kemungkinan yang terjadi bisa disebabkan oleh distorsi citra tubuh. Sehingga munculah perilaku gangguan makan dengan membatasi jumlah dan beberapa jenis makanan. Pada akhirnya menyebabkan anemia.

Pada penelitian ini responden yang memiliki status gizi lebih ternyata juga mengalami anemia. Hasil dietary history menujukkan bahwa asupan zat gizi mikro yang diperlukan untuk pembentukan hemoglobin sangat rendah. WUS yang obesitas sangat rentan terkena anemia dibandingkan dengan wanita normal melalui penurunan status besi. Hal ini diperkuat oleh sebuah penelitian yang menyatakan bahwa sebanyak 20\% WUS obesitas memiliki status besi yang rendah (Nurramadhani et al., 2019).

Pada orang yang obesitas terjadi penumpukan lemak dalam tubuh (adipositas). Selain itu, produksi hepsidin ke dalam sirkulasi portal lebih tinggi (Domenico et al., 2010). Produksi hepsidin yang berlebihan akan menghambat penyerapan besi.

Hasil penelitian ini sejalan dengan penelitian di KUA Kebon Jeruk bahwa status gizi tidak memiliki hubungan dengan kejadian anemia (Sundaniawati, 2018). Penelitian lain juga menyebutkan bahwa masih terdapat kejadian anemia ringan $(\mathrm{Hb} 10-11 \mathrm{~g} / \mathrm{dl})$ pada status gizi normal (5,5\%) maupun gemuk $(3,6 \%)$ (Abidin et al., 2012).

\section{KESIMPULAN DAN SARAN}

\section{Kesimpulan}

1. Ada hubungan antara citra tubuh dan status anemia.

2. Tidak ada hubungan antara kecukupan zat gizi dan status anemia.

3. Tidak ada hubungan antara status gizi dan status anemia.

\section{Saran}

1. Bagi calon pengantin perlu memperhatikan kuantitas dan 
kualitas makanan yang dikonsumsi agar keseimbangan zat gizi di dalam tubuh dapat terjaga dengan baik.

2. Bagi penelitian selanjutnya perlu memperhatikan waktu yang tepat dalam mengambil data asupan makan. Saat menjelang pernikahan memungkinkan terjadi perubahan perilaku makan.

\section{DAFTAR PUSTAKA}

Abidin, I., Supriyadi, \& Sumbara. (2012). Hubungan Indeks Massa Tubuh (IMT) dengan Kejadian Anemia pada Remaja Putri di SMA Kifayatul Achyar Wilayah Kec. CibiruBandung Tahun 2012. Bhakti Kencana Medika, 2(4), 2-6.

Akib, A., \& Sumarmi, S. (2017).

Kebiasaan Makan Remaja Putri yang Berhubungan dengan Anemia :

Kajian Positive Deviance. Amerta N, 105-116.

Amar, M. I., Puspita, I. D., \& Nasrullah, N. (2018). Implementasi Program Bimbingan Persepsi Positive Body Image Terhadap Pengetahuan Gizi Remaja dan Satus Gizi Remaja Putri. Al-Sihah: Public Health Science Journal, 10, 1-11.

Aminullah, A. E. (2016). Hemoglobin pada Remaja Puteri dan Kadar Hemoglobin pada Remaja Puteri di
SMK N 1 Sewon Bantul. (Skripsi). Yogyakarta. Universitas 'Aisyiyah Yogyakarta.

Badjree, K. A., \& Muniroh, L. (2017). Hubungan Body Image, Asosiasi Emosional, dan Pola Konsumsi dengan Status Anemia Pramugari. Media Gizi Indonesia, 12(2), 141148.

Domenico, I. De, Zhang, T. Y., Koening, C. L., Branch, R. W., London, N., Lo, E., ... Kaplan, J. (2010). Hepcidin Mediates Transcriptional Changes that Modulate Acute CytokineInduced Inflammatory Response in Mice. The Journal of Clinical Investigation, 120(7), 2395-2405.

Fatimah, S. (2016). Hubungan Persepsi Tubuh (Body Image) Terhadap Status Anemia pada Remaja Putri di SMA Sederajat Kabupaten Bantul. (Skripsi). Yogyakarta. Universitas Alma Ata Yogyakarta.

Houghton, L. A., Parnell, W. R., Thomson, C. D., Green, T. J., \& Gibson, R. S. (2016). Serum Zinc Is a Major Predictor of Anemia and Mediates the Effect of Selenium on Hemoglobin in School-Aged Children in a Nationally Representative Survey in New Zealand. Journal of Nutritition, 146(9), 1670-1676.

Jain, N., Prasuna, J. G., \& Khandekar, J. (2015). Self Body Image and 
Perceived Health in Adolescents : A Facility Based Study. ADR Journals, 2(1\&2), 8-15.

Li, K.-K., Concepcion, R. Y., Lee, H., Cardinal, B. J., Ebbeck, V., Woekel, E., \& Readdy, R. T. (2012). An Examination of Sex Differences in Relation to the Eating Habits and Nutrient Intakes of University Students. Journal of Nutrition Education and Behavior, 44(3).

Matayane, S. G., Bolang, A. S. L., \& Kawengian, S. E. S. (2014). Hubungan Antara Asupan Protein dan Zat Besi dengan Kadar Hemoglobin Mahasiswa Program Studi Pendidikan Dokter Angkatan 2013 Fakultas Kedokteran Universitas Sam Ratulangi. Jurnal E-Biomedik, 2(3). Muchlisa. (2013). Hubungan Asupan Zat Gizi dengan Status Gizi pada Remaja Putri di Fakultas Kesehatan Masyarakat Universitas Hasanudin Makasar tahun 2013. (Skripsi).

Makassar. Universitas Hassanuddin.

Murray, R. K., Granner, D. K., \& W., V. R. (2009). Biokimia Harper (27th ed.). Jakarta: Buku Kedokteran EGC.

Negash, C., Whiting, S. J., Henry, C. J., \& Belachew, Tefera Hailemariam, T. G. (2015). Association between Maternal and Child Nutritional Status in Hula, Rural Southern Ethiopia: A Cross Sectional Study. PLoS One, 10(11),
$1-8$.

Nurramadhani, S. R., Dieny, F. F., Murbawani, E. A., Tsani, A. F. A., Fitranti, D. Y., \& Widyastuti, N. (2019). Status Besi dan Kualitas Diet berdasarkan Status Obesitas pada Wanita Usia Subur di Semarang. Amerta Nutrition, 3(4), 247-256.

Paratmanitya, Y., Hadi, H., \& Susetyowati. (2012). Citra Tubuh , Asupan Makan , dan Status Gizi Wanita Usia Subur Pranikah. Jurnal Gizi Klinik Indonesia, 8(3), 126-134.

Prichard I, \& Tiggemann M. (2008). An Examination of Pre-Wedding Body Image Concerns in Brides and Bridesmaids. Body Image, 5(4), 395398.

Putro, K. Z. (2017). Memahami Ciri dan Tugas Perkembangan Masa Remaja. Aplikasia, 17, 25-32.

Rahmah, P. Y. (2018). Kesiapan Membangun Rumah Tangga (Studi Kasus Remaja Putri K-Popers Kota Malang). (Skripsi). Malang. Universitas Islam Negeri Malang.

Sari, Y., Khasanah, A. N., \& Sartika, S. (2016). Studi Mengenai Kesiapan Menikah pada Muslim Dewasa Muda. In Prosiding Seminar Nasional Penelitian dan PKM Kesehatan (Vol. 6, pp. 193-204). UNISBA.

Simanungkalit, S. F., \& Simarmata, O. S. (2019). Pengetahuan dan Perilaku 
Konsumsi Remaja Putri yang

Berhubungan dengan Status Anemia.

Buletin Penelitian Kesehatan, 47(3), 175-182.

Sudikno, \& Sandjaja. (2016). Prevalensi dan Faktor Risiko Anemia pada Wanita Usia Subur di Rumah Tangga Miskon di Kabupaten Tasikmalaya dan Ciamis, Provinsi Jawa Barat. Jurnal Kesehatan Reproduksi, 7(2), 71-82.

Sulistyan, A., Huryati, E., \& Hastuti, J. (2016). Distorsi Citra Tubuh, Perilaku Makan, dan Fad Diets pada Remaja Putri di Yogyakarta. Jurnal Gizi Klinik Indonesia, 12(3), 99-108.

Sundaniawati, I. (2018). Hubungan Antara Karakteristik, Status Gizi, Konsumsi Tanin, Tingkat Stres, dan Kejadian Anemia Calon Pengantin Wanita di KUA Kebon Jeruk Jakarta Barat. (Skripsi). Jakarta. Universitas Esa Unggul.

Syafangah, U. (2017). Hubungan Tingkat
Pendidikan dan Pekerjaan dengan Pernikahan Dini pada Remaja Putri di Kecamatan Gamping Kabupaten Sleman Tahun 2016. In (Skripsi). Yogyakarta. Universitas 'Aisyiyah Yogyakarta.

Syah, M. N. H., \& Asna, A. F. (2018). Risiko Gangguan Makan dan Kejadian Anemia pada Mahasiswa Putri Program Studi S1 Gizi STIKES Mitra Keluarga. Ghidza: Jurnal Gizi Dan Kesehatan, 2(1), 1-6.

Yusintha, A. N., \& Adriyanto. (2018). Hubungan Antara Perilaku Makan dan Citra Tubuh dengan Status Gizi Remaja Putri Usia 15-18 Tahun. Amerta Nutrition, 147-154. 